\title{
Urochloa Hybrid Submitted to Biostimulant Application in Grazing Simulation
}

\author{
Luara Cristina de Lima ${ }^{1}$, Renato Aurélio Severino de Menezes Freitas ${ }^{1}$, Leandro Martins Barbero ${ }^{2}$, \\ Regina Maria Quintão Lana ${ }^{1}$, Fernanda Carvalho Basso ${ }^{3}$, Atalita Francis Cardoso ${ }^{3} \&$ Reginaldo de Camargo ${ }^{1}$ \\ ${ }^{1}$ Institute of Agrarian Sciences, Federal University of Uberlândia, Brazil \\ ${ }^{2}$ Faculty of Veterinary Medicine, Federal University of Uberlândia, Brazil \\ ${ }^{3}$ University Center of Goiatuba, Brazil \\ Correspondence: Luara Cristina de Lima, Institute of Agrarian Sciences, Federal University of Uberlândia, \\ Uberlândia, Brazil. Tel: 55-34-98812-4119. E-mail: lima_luara@yahoo.com.br
}

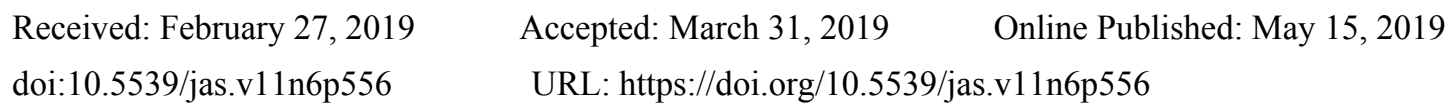

The research is financed by Coordination for the Improvement of Higher Education Personnel (CAPES) and Stoller ${ }^{\circledR}$.

\begin{abstract}
The objective of this work was to evaluate the performance of Urochloa hybrid Convert HD364 applied in different doses as a vegetable biostimulant under grazing simulation in intermittent stocking in the city of Uberlândia, Minas Gerais. The treatments consisted of a control (absence of biostimulant) and in 5 doses of biostimulant, $0.25 ; 0.5 ; 0.75 ; 1.0$ and $1.25 \mathrm{~L} \mathrm{ha}^{-1}$, in a randomized complete block design with 4 replicates. Productive and qualitative parameters were evaluated. The data were submitted to analysis of variance, using for the comparison of means, the Regression test at $5 \%$ of significance. The biostimulant promotes an increase in the accumulation of DM and in the rate of accumulation of forage, leaves and stems of Urochloa hybrid and reduction in the percentage of dead material and the L:S ratio of Urochloa hybrid.
\end{abstract}

Keywords: Urochloa hybrid Convert HD364, plant hormones, fodder, plant nutrition

\section{Introduction}

Forage production is preponderant in Brazilian livestock as it deals with the most economical and practical way of producing food for most of the Brazilian cattle herd due to the low cost of production provided by pastures when compared to confinement systems (Berchielli et al., 2012).

The use of new fertilizer technologies, such as the use of biostimulants, when applied externally in plants, promote activities similar to phytohormone groups that aid in defense mechanisms, promote growth and development (Neto et al., 2014), act as activators of plant cell metabolism, provide vigor to the immune system, and reactivate physiological processes in the different stages of plant development (Silva et al., 2010).

In recent years, some studies have been carried out with the use of biostimulants in annual and perennial plants and presented controversial results in which positive results were found by authors such as Albrecht et al. (2009) in cotton; Castro et al. (2008); Albrecht et al. (2011) and Albrecht et al. (2012) in soybean; Costa et al. (2010) in coffee and De Almeida et al. (2014) in beans. On the other hand, Ferreira et al. (2007) in corn and Rampim et al. (2012) in wheat did not obtain answers with the application of biostimulant.

In Brazil, the expansion of cultivated pasture areas has occurred in large proportions, especially with species of the genus Urochloa, and probably was never equaled by other forages in any other tropical country (Costa et al., 2007). The Urochloa hybrid Convert HD364 is the result of crossing in three generations: Urochloa ruziziensis $\times$ Urochloa decumbens cv. Basilik and the crosses of the progenies obtained in the first crossing with Urochloa brizantha cv. Marandu (Argel et al., 2007).

The hybrid grass Convert HD364 combines productivity, resistance and digestibility, since it has wide adaptability to varied climatic and soil conditions (Santos et al., 2015). However, according to Fagundes et al. 
(2005), even if the production potential of a fodder plant is determined genetically, for this potential to be achieved appropriate conditions of the environment and management must be observed.

The objective of this work was to evaluate the performance of the Urochloa hybrid Convert HD364, used as a biostimulant under grazing simulation significance.

\section{Materials and Methods}

The experiment was carried out in the experimental area of the Forragicultura nucleus at Fazenda Capim Branco, in the municipality of Uberlândia, Minas Gerais, at coordinates $18^{\circ} 52^{\prime} 55^{\prime \prime} \mathrm{S}$ and $48^{\circ} 20^{\prime} 28^{\prime \prime} \mathrm{W}$, at an altitude of $805 \mathrm{~m}$, in the period between November 2014 and March 2015.

The climate of the region is classified by the method of Köppen, as Aw, tropical hot and humid, with cold and dry winter. The average annual rainfall is $1606 \mathrm{~mm}$ and the average annual temperature is $21.5^{\circ} \mathrm{C}$ with $1479 \mathrm{~mm}$ of annual average rainfall (Rolim et al., 2007). From the climatic data collected at the meteorological station in the vicinity of the experimental area, during the conduction period of the experiment, the precipitation and the average temperature are shown in Figure 1.

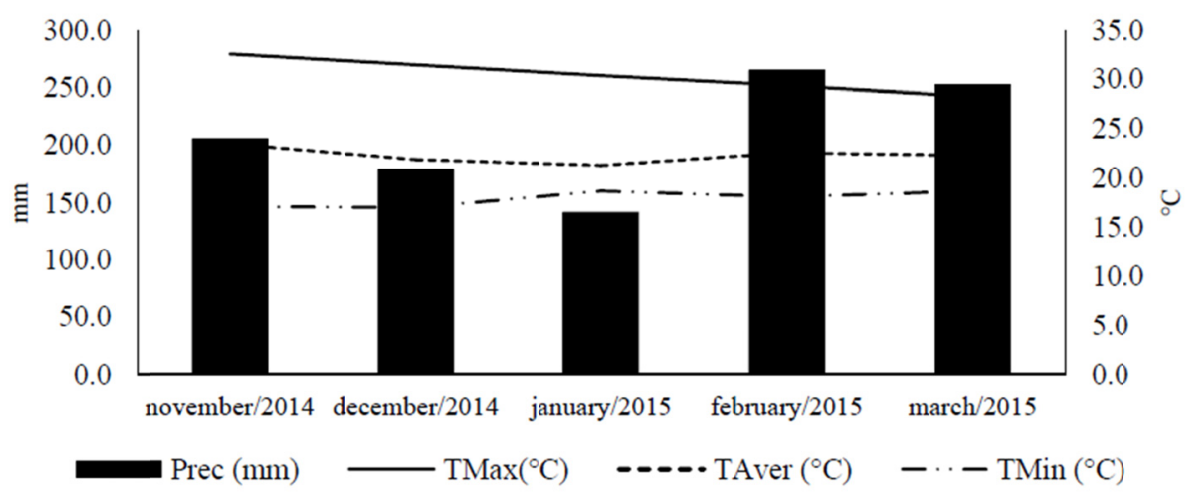

Figure 1. Maximum temperature, minimum temperature and average temperature and precipitation in the experimental area of Urochloa hybrid Convert HD364

The experiment was carried out in a dark red clay latosol (Santos et al., 2013). Before the installation of the experiment, the soil was collected and the chemical analysis was carried out for the purpose of ascertaining the fertility (Table 1).

Table 1. Chemical characterization of soil in the experimental area of Urochloa hybrid Convert HD364

\begin{tabular}{|c|c|c|c|c|c|c|c|c|c|}
\hline $\mathrm{pH}$ & $P$ & K & $\mathrm{Ca}$ & $\mathrm{Mg}$ & $\mathrm{Al}$ & O.M. & SB & $\mathrm{T}$ & $\mathrm{V}$ \\
\hline $\mathrm{H}_{2} \mathrm{O}$ & \multicolumn{2}{|c|}{----- $\mathrm{mg} \mathrm{dm}^{-3}$----- } & \multicolumn{3}{|c|}{ - $\mathrm{cmol}_{\mathrm{c}} \mathrm{dm}^{-3}$---- } & \multicolumn{2}{|c|}{ dag $\mathrm{kg}^{-1}$} & \multicolumn{2}{|c|}{------- \% -------- } \\
\hline 5.5 & 1.6 & 118.0 & 2.0 & 0.9 & 0.0 & 3.8 & 3.2 & 7.9 & 40.0 \\
\hline
\end{tabular}

Note. $\mathrm{P}=$ Method Mehlich1, $\mathrm{P}, \mathrm{K}=\left[\mathrm{HCl} 0.05 \mathrm{~mol} \mathrm{~L}^{-1}+\mathrm{H}_{2} \mathrm{SO}_{4} 0.0125 \mathrm{~mol} \mathrm{~L}^{-1}\right], \mathrm{Ca}, \mathrm{Mg}, \mathrm{Al}=\left[\mathrm{KCL} 1 \mathrm{~mol} \mathrm{~L}^{-1}\right]$, O.M. $=$ Colorimetric Method, $\mathrm{SB}=$ Sum of base, $\mathrm{V}=$ Base saturation; $\mathrm{T}=\mathrm{CTC}$ at $\mathrm{pH}$ 7.0.

The sowing of the Urochloa hybrid was carried out in November of 2013. The conduction of the experiment began on November 23, 2014 and ended on March 28, 2015.

The experimental design was a randomized complete block (DBC) with 6 treatments and 4 replicates. The treatments were composed by a control (absence of biostimulant) and doses of biostimulant. The doses used were: $0.25 ; 0.5 ; 0.75 ; 1.0$ and $1.25 \mathrm{~L} \mathrm{ha}^{-1}$. In all treatments, after application by foliar biostimulant, $30 \mathrm{~kg} \mathrm{ha}^{-1}$ of $\mathrm{N}$ (Nitrogen) was applied following the recommendation (Cantarutti, 2007). The biostimulant used presents in its composition synthetic substances with actions similar to the plant hormones cytokinin, gibberellin and auxin. The biostimulant dose, adjuvant at $0.5 \%$ solution concentration, was added.

The first foliar application of the solution was performed after the standardization cut on November 24, 2014, after which three more applications were applied at intervals of 23, 56 and 60 days. The application of the doses 
of the biostimulant was carried out with the aid of a pressurized $\mathrm{CO}_{2}$ costal spray, equipped with a 2 meter bar and 4 fan-type nozzles, with a volume of $200 \mathrm{~L} \mathrm{ha}^{-1}$ being applied.

For the evaluation of the following variables: leaf content and accumulation of macro and micronutrients of the aerial part; forage accumulation (DM-dry mass) and RA (rate of accumulation) of forage; concentration of PB (crude protein), NDF (neutral detergent fiber) and ADF (acid detergent fiber); relation of L:S (leaf:steam) and RA of leaves, stem and dead material and root mass, the forage mass and reference leaf were collected previously to the cuts made in total area, homogenizing and separating the materials at the end of the experiment.

The last fully expanded leaf per plant unit was randomly collected, referred to as the reference leaf, totaling 30 units per plot (Malavolta, 2006). These were placed in paper bags and fed to the forced air circulation oven at a temperature of $65^{\circ} \mathrm{C}$ for a period of 72 hours. After drying, the samples were passed through the milling process in Willey mill $(2 \mathrm{~mm})$, identified and sent to the Brazilian Laboratory of Agricultural Analysis LTDA (LABRAS), Monte Carmelo, MG.

The methods used for the determination of the macro and micronutrients were: sulfuric digestion of $\mathrm{N}$ (Total $\mathrm{N}$ ), nitro perchloric digestion for Phosphorus (P), Potassium (K), Calcium (Ca), Magnesium (Mg), Sulfur Copper $(\mathrm{Cu})$, Iron (Fe), Manganese (Mn), Zinc ( $\mathrm{Zn}$ ) and incineration to Boro (B) (Malavolta, 2006). For accumulation of macro and micronutrients in the forage, the foliar content of each nutrient was multiplied by the accumulation of leaf DM in $\mathrm{kg} \mathrm{ha}^{-1}$.

For analyzes of forage accumulation and forage RA; the concentrations of CP, NDF and ADF; percentage, accumulation and RA of leaves, stem and dead material and the relation of L:S, the forage mass of Urochloa hybrid was collected in 2 areas delimited within each plot with the aid of a metallic square $(1.00 \times 0.50 \mathrm{~m})$, which was cut at random, being cut at $15 \mathrm{~cm}$ from the ground level. The sample from each plot was homogenized, separated into subsamples and placed in identified plastic bags.

In order to determine the accumulation of forage, the sub sample was first weighed to produce the green mass, then taken to the forced circulation oven at $65^{\circ} \mathrm{C}$ for a period of 72 hours, performing the forage weighing (DM). By means of the relationships between green mass and forage, the percentage of forage (\% DM) was calculated and from that value the accumulation of forage in $\mathrm{kg} \mathrm{ha}^{-1}$.

After determining the accumulation of forage, the sub-sample was initially milled in a Willey mill (2 $\mathrm{mm})$. Afterwards, they were stored in plastic bags to perform CP, NDF and ADF analysis.

$\mathrm{N}$ total determinations were performed according to Kjeldahl semimicro method (Nogueira \& Souza, 2005). From the total $\mathrm{N}$ values, the $\mathrm{CP}$ content was estimated by multiplying it by the conversion factor of 6.25 , considering that the proportion of $\mathrm{N}$ in the plant proteins is equal to 16\% (Campos et al., 2004).

The determination of the lignin content is performed from the ADF concentration, as described by Silva and Queiroz (2006) and the evaluations of the concentrations of NDF followed the protocols suggested by Mertens (2002).

For the evaluation of the morphological composition, the material was fractionated, with the aid of a scissors, in leaves (green slides), stems (stem and leaf sheaths) and dead material. After separation, each fraction was placed in a paper bag, weighed and taken to the forced circulation oven at a temperature of $65{ }^{\circ} \mathrm{C}$ for a period of 72 hours. Then they were weighed again. The weighing data were used to calculate the percentage of forage of each morphological component in relation to the total forage of the sub-sample.

From the percentage of each component, the accumulation of forage of leaves, stems and dead material per hectare was calculated.

Accumulation of forage of component $=\%$ of Component $\times$ Accumulation of forage in $\mathrm{kg} \mathrm{ha}^{-1}$.

For the calculation of relation of L:S, the percentage of leaves was divided by the percentage of stem.

RA was given by the accumulation of forage, total forage accumulation of each morphological component (leaf, stem and dead material) divided by the total number of days of the period.

A collection of roots mass samples was carried out in the water period, in which the entire clump was removed with a pair of scissors, collecting four points with the aid of a root sampling probe, at three depths, forming a sample composed of each depth and conditioning them in identified plastic bags.

The roots were washed, removing all soil and impurities according to Kanno et al. (1999) by storing the root samples in identified paper bags and placing them in a forced air circulation oven at a temperature of $65^{\circ} \mathrm{C}$ for a 
period of 72 hours. After this period the samples were weighed and weighed, estimating root masses $\left(\mathrm{kg} \mathrm{m}^{-3}\right.$ of DM) at depths of 0-10, 10-20, 20-40 and 0-40 cm.

The results were first submitted to the assumptions, homogeneity, heterogeneity and additivity tests, in order to evaluate the residues normality and the homogeneity of the variances, respectively. After that, the data were submitted to analysis of variance. For the evaluation of the effects of biostimulant doses, we used polynomial regressions at 1 and $5 \%$ significance.

\section{Results and Discussion}

The use of biostimulant promoted interference in the accumulation of DM from forage, leaves and stems of Urochloa hybrid $(p>0.05)$, where as DM accumulation of dead material was not influenced $(p>0.05)$ (Table 2).

Table 2. Parameters for forage production in Urochloa hybrid Convert HD364, submitted to the foliar application of biostimulant $\left(\mathrm{L} \mathrm{ha}^{-1}\right)$

\begin{tabular}{|c|c|c|c|c|c|c|c|c|c|c|c|c|}
\hline Doses of biostimulant & $\overline{\mathrm{AF}}$ & $\mathrm{AL}$ & $\overline{\text { AS }}$ & ADM & RAF & RAL & RAS & RADM & Leaf & Stem & Dead material & $\mathrm{L}: \mathrm{S}$ \\
\hline $\mathrm{L} \mathrm{ha}^{-1}$ & \multicolumn{4}{|c|}{----- $\mathrm{kg} \mathrm{ha}^{-1}$ of DM ------ } & \multicolumn{4}{|c|}{---- $\mathrm{kg} \mathrm{ha}^{-1} \mathrm{dia}^{-1}$ of DM ---- } & \multicolumn{4}{|c|}{-------------- \% -------------- } \\
\hline 0 & 6414 & 5470 & 587 & 357 & 49.1 & 42.3 & 3.3 & 0.2 & 85.3 & 8.5 & 6.2 & 9.3 \\
\hline 0.25 & 6551 & 5509 & 673 & 368 & 53.3 & 46.0 & 3.9 & 0.2 & 84.0 & 8.6 & 6.3 & 9.3 \\
\hline 0.50 & 7322 & 6196 & 787 & 339 & 59.5 & 52.4 & 4.2 & 0.2 & 86.3 & 9.5 & 4.9 & 8.6 \\
\hline 0.75 & 7451 & 6015 & 1042 & 393 & 60.6 & 50.8 & 5.9 & 0.3 & 81.5 & 14.0 & 5.8 & 5.9 \\
\hline 1.00 & 8634 & 7226 & 1067 & 421 & 70.2 & 61.6 & 5.3 & 0.2 & 83.8 & 12.0 & 5.3 & 6.8 \\
\hline 1.25 & 10068 & 8398 & 1285 & 385 & 81.9 & 70.0 & 8.0 & 0.3 & 84.5 & 12.8 & 4.2 & 6.8 \\
\hline C.V. $(\%)$ & 7.15 & 8.53 & 20.40 & 22.73 & 8.72 & 9.43 & 25.05 & 22.35 & 2.52 & 14.60 & 15.22 & 11.15 \\
\hline${ }^{1} \mathrm{P}$ & $* *$ & $* *$ & $* *$ & ns & $* *$ & $* *$ & $* *$ & $\mathrm{~ns}$ & $\mathrm{~ns}$ & $* *$ & $*$ & $* *$ \\
\hline
\end{tabular}

Note. AF: accumulation of DM of forage; AL: Accumulation of DM of leaves; AS: Accumulation of DM stems; ADM: accumulation of DM of dead material; RAF: rate of forage accumulation; RAL: rate of accumulation of leaves; TAS: rate of accumulation of stems; RADM: The rate of accumulation of dead material; L:S: relation of leaf:stem; C.V. (\%): Coefficient of variation. P-value: ** significance to $1 \%$; * significance to $5 \%$.

The increases in DM accumulations promoted by the use of biostimulants ranged from 12.7 to $40.2 \%$ in forage; 15.3 to $38.7 \%$ in the leaves and 2.6 to $85.5 \%$ in the stems in relation to the control (Table 2), this increase was related to the fact that the biostimulant contains synthetic substances with functions similar to phytohormones, acting in the growth and plant development, since they function as highly specific chemical signals between cells (De Campos et al., 2015). Serciloto et al. (2008) demonstrated an increase in yield of orange pear with the application of foliar biostimulator at $8 \mathrm{mg} \mathrm{L}^{-1}$ when the plants presented $25 \%$ of open flowers.

The reduction of the relation of L:S may be related to the greater accumulation of DM in the shoots in relation to the leaves in the treatments in which they used doses of biostimulant (Figure 3). In addition, the substances present in the biostimulant act to retard the aging of the plant, stimulating the cell division, the development of lateral buds and the caulinar cell stretching. Thus, the increase of the doses of biostimulants contributed to the reduction in the relation of L:S $(p<0.05)$ (Figure 3). The percentage of leaf, stem and dead material were not influenced $(\mathrm{p}>0.05)$ by the biostimulant (Table 2$)$.

From the data of percentage of leaf, stem and dead material in the time of the waters (Table 2) it was observed that the relation of L:S was similar for all the treatments. For a good development of forage grass species an ideal temperature and precipitation condition is required, the mean values of precipitation and temperature were $200 \mathrm{~mm}$ and $25{ }^{\circ} \mathrm{C}$, respectively. In January of 2015 , the average temperature was above $25^{\circ} \mathrm{C}$ and the average precipitation was below $200 \mathrm{~mm}$, which affected the process of photosynthesis and evapotranspiration, and consequently made the plant processes as absorption and less active transport, thus impairing the accumulation of live material (leaves + stems) (Figure 1).

The critical limit of the relation of L:S is equal to 1.00. In this study, in all treatments, the relation was higher than this limit for the two seasons (Table 2) (Bonfim-Silva et al., 2010). Due to the high precipitation (Figure 1), it offered better conditions to the tillering of the plants, and consequently favored the relation of L:S. The importance of these data is related to forage quality, since the higher relation promotes a better digestibility of the plant material, and as a result, better animal production. 
The RA of forage, leaves and stems were not interfered with by the biostimulant (Table 2) $(p>0.05)$. Some phytohormones of the auxin group at high concentrations, instead of stimulating growth, may inhibit it (Taiz \& Zeiger, 2013), basing the result obtained, since in the higher doses of biostimulant the RA of forage decreased to reach the value of $68.7 \mathrm{~kg} \mathrm{ha}^{-1} \mathrm{day}^{-1}$ of DM of Urochloa hybrid at the dose of $1.25 \mathrm{~L} \mathrm{ha}^{-1}$ of biostimulant (Table 2).

De Mattos et al. (2008) in evaluating the forage accumulation and RA of the aruana grass, verified values similar to those identified in this study. However, Fagundes et al. (2006) reported the relative participation of the stem component in the RA of the forage of Urochloa decumbens, where the contributions were $62 \%$ in the summer, contradicting with the result found, where the contributions were around $8 \%$ (Table 2).

Biostimulants are chemicals that stimulate cell elongation and cell division, aiding the development of the plant, as well as providing increased absorption and utilization of water and nutrients, depending on the composition and concentration of these products (Taiz \& Zeiger, 2013).

Some substances such as kinetin, when applied to certain plant organs, act along with auxin, increasing cell divisions. Kinetin is derived from adenine (or aminopurine), and is involved in regulating growth and differentiation, including apical dominance, organ formation, leaves, stomatal opening, bud and bud growth, nutrient metabolism, and as a regulator of gene expression (Vieira, 2011).

Auxins present a wide range of physiological effects on plants, such as their participation in cell stretching. They have synergistic interaction with cytokinins in the regulation of cell division processes, and when exogenously applied to the plant these two hormones control the organogenesis of roots and branches, in which the high concentrations of auxin induce the formation of roots, while the high concentrations of cytokinin induce the formation of branches. Therefore, the effects of plant hormones are dependent on the concentration, interaction with other hormones, the stage of development and the type of organ or tissue of the plant (Taiz \& Zeiger, 2013; Kerbauy, 2008).

The substances found in the biostimulants acted to slow the aging of the plant, due to the stimulation of the cell divisions, the development of the lateral buds and the caulinar cell elongation (Table 2).

The accumulation of forage and leaf DM fitted the quadratic model, in which, for forage, the minimum dose of $0.02 \mathrm{~L} \mathrm{ha}^{-1}$ produced an accumulation of $6462.6 \mathrm{~kg} \mathrm{ha}^{-1}$ of DM and for leaves, the dose minimum of $0.12 \mathrm{~L} \mathrm{ha}^{-1}$ produced an accumulation of $5498.5 \mathrm{~kg} \mathrm{ha}^{-1}$ of DM. The accumulation of DM of stalk was framed in the linear model in which the maximum dose used of $1.25 \mathrm{~L} \mathrm{ha}^{-1}$ promoted a DM accumulation of $1285.0 \mathrm{~kg} \mathrm{ha}^{-1}$ (Figure 2).
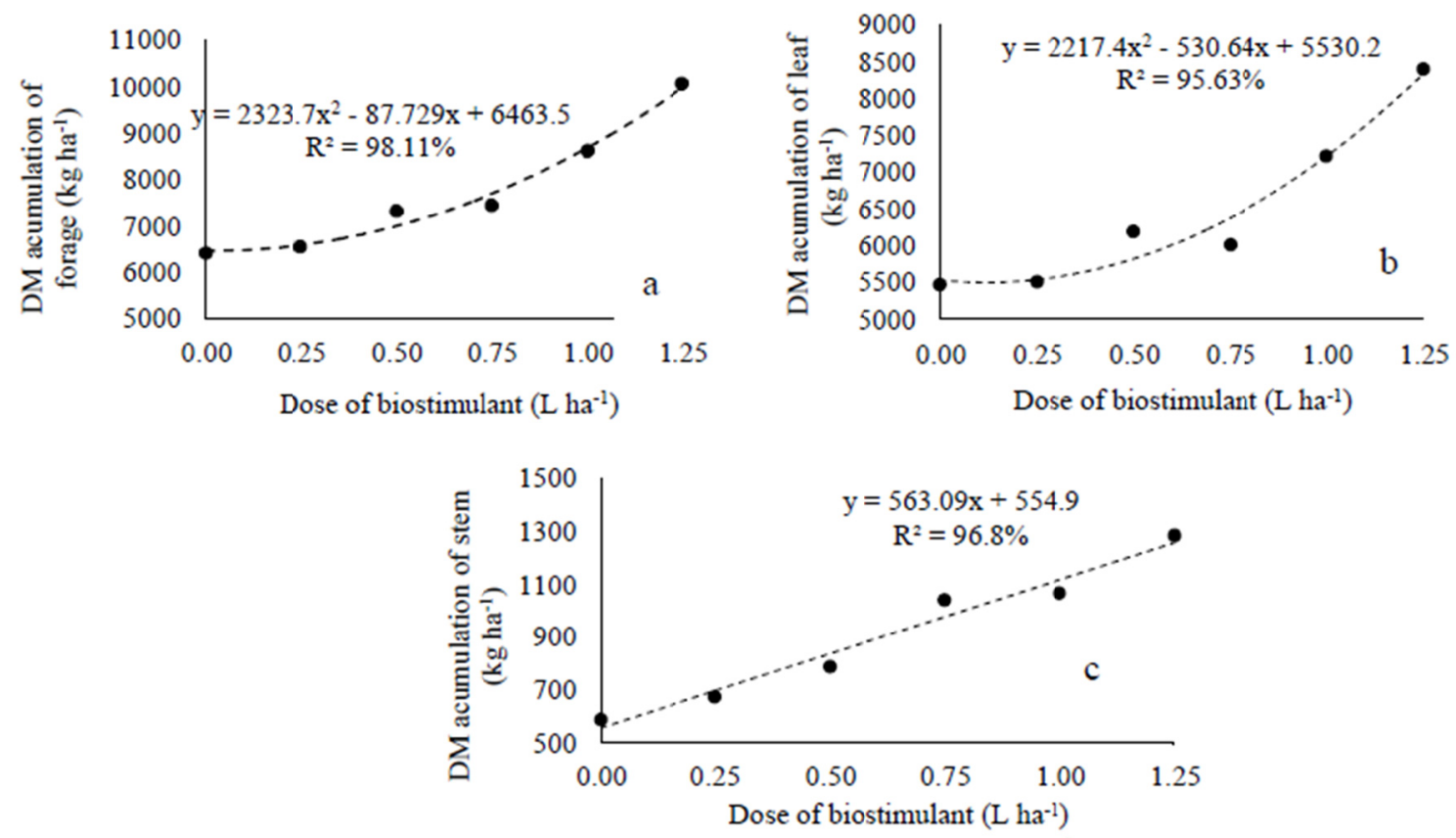

Figure 2. DM accumulations of forage (a), leaf (b) and (c) stem ( $\mathrm{kg} \mathrm{ha}^{-1}$ of DM) Urochloa hybrid subjected to foliar application of biostimulant $\left(\mathrm{L} \mathrm{ha}^{-1}\right)$ 
The high precipitation in the water season (Figure 1) can be related to high production of live material (leaves + stems) and the small amount of dead material in all treatments (Table 2), demonstrating the connection between soil moisture and the increase in DM production, which influenced the development of the plant, due to water being one of the main factors of production, and to be closely linked to the photosynthetic process; transport of substances in the plant and absorption processes.

When analyzing the relation of $\mathrm{L}: \mathrm{S}$ at the time of the waters, the linear fit was the best fit, with a minimum ratio of 6.3 at the dose $1.25 \mathrm{~L} \mathrm{ha}^{-1}$ (Figure 3). This decrease may be related to the increasing doses of biostimulant, providing a greater accumulation of forage in the shoots with respect to the leaves and, consequently, the reduction in this relation.

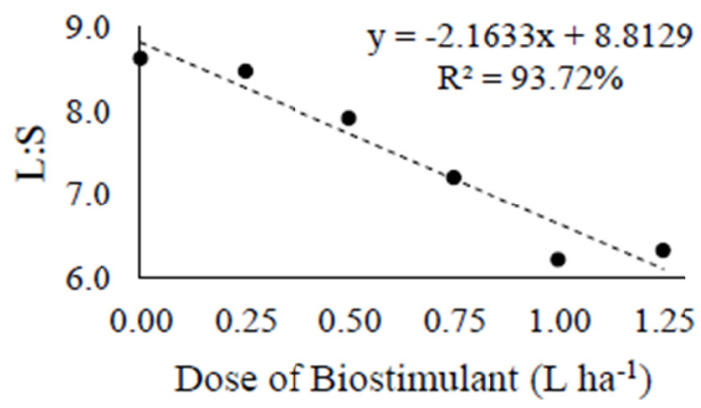

Figure 3. Relation of Leaf:Stem (L:S) Urochloa hybrid in function of different doses of biostimulant

The plants cultivated in the field are subject to water deficit, usually occurring alterations of metabolic, whose importance depends on their intensity and duration, including the reduction of cell development, leaf expansion, transpiration and reduction in photoassimilate translocation and among environmental factors, which most often limits the development of crops (Nogueira \& Santos, 2000).

The biostimulant used has in its composition synthetic substances with functions similar to the phytohormones of the cytokinins and auxins group, in which it promotes root branching (Taiz \& Zeiger, 2013), due to cellular elongation. This was not corroborated with the results found in the present study, in which no dose of biostimulant interfered $(p>0.05)$ in root density at different depths (Table 3$)$.

Table 3. Density of roots of Urochloa hybrid Convert HD364 in layers of 0-10;10-20; 20-40 and 0-40 cm in function of different doses of biostimulant

\begin{tabular}{|c|c|c|c|c|}
\hline Doses of biostimulants & $0-10$ & $10-20$ & $20-40$ & $0-40$ \\
\hline $\mathrm{L} \mathrm{ha}^{-1}$ & \multicolumn{4}{|c|}{ - kg m ${ }^{-3}$ of DM } \\
\hline 0.00 & 63.47 & 48.45 & 21.12 & 136.09 \\
\hline 0.25 & 81.25 & 45.14 & 24.13 & 151.15 \\
\hline 0.50 & 75.55 & 48.76 & 21.12 & 146.11 \\
\hline 0.75 & 77.65 & 52.47 & 22.37 & 152.46 \\
\hline 1.00 & 71.19 & 52.23 & 21.69 & 142.15 \\
\hline 1.25 & 73.10 & 48.05 & 21.73 & 142.61 \\
\hline $\mathrm{CV}$ & 8.40 & 9.14 & 8.05 & 5.21 \\
\hline $\mathrm{P}^{1}$ & ns & ns & ns & ns \\
\hline
\end{tabular}

Note. C.V. (\%): Coefficient of variation. P-value: ns: not significance to $1 \%$ and $5 \%$.

External factors such as high precipitation during the water season (Figure 1) provided an environment conducive to the development of the Urochloa hybrid interfering in the expansion of the area by the roots. The need for water by the plant for development was supplied near the surfaces of the roots, and root expansion was not required for Urochloa hybrid.

The percentages of ADF, NDF and CP of the Urochloa hybrid were not interfered with $(\mathrm{p}>0.05)$ in the doses of biostimulant (Table 4). 
Table 4. Nutritive value of Urochloa hybrid in function of different doses of biostimulant

\begin{tabular}{|c|c|c|c|}
\hline Doses of biostimulants & $\mathrm{NDF}$ & $\mathrm{ADF}$ & $\mathrm{CP}$ \\
\hline $\mathrm{L} \mathrm{ha}^{-1}$ & \multicolumn{3}{|c|}{ 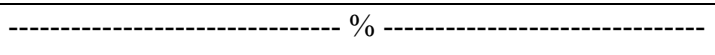 } \\
\hline 0.00 & 57.95 & 28.72 & 7.97 \\
\hline 0.25 & 54.59 & 27.95 & 8.80 \\
\hline 0.50 & 57.42 & 28.64 & 9.96 \\
\hline 0.75 & 56.19 & 27.26 & 8.96 \\
\hline 1.00 & 57.85 & 28.21 & 8.99 \\
\hline 1.25 & 57.25 & 28.23 & 9.53 \\
\hline $\mathrm{CV}$ & 3.50 & 3.91 & 9.17 \\
\hline $\mathrm{P}^{1}$ & ns & ns & ns \\
\hline
\end{tabular}

Note. C.V. (\%): Coefficient of variation. P-value: ns: not significance to $1 \%$ and $5 \%$.

Regarding NDF, all treatments with doses of biostimulants (Table 4) were below the value indicated by Serafim (2010). For this author, in the management of pastures aiming at the production of ruminant animals, obtaining forage with the NDF content above $65 \%$ did not promote losses in DM consumption (forage) by cattle, but in a condition below this value gives ruminal microorganisms greater use of nutrients.

In the comparison of the percentage of NDF (Table 4) with those found in the literature, it was found that this was below those recorded by Velásquez et al. (2010) for Urochloa brizantha cv. Marandu, Corrêa et al. (2007) for coastcross grass and Paciullo et al. (2009) for Urochloa decumbens.

The percentage of ADF was found to be between 27 and $28.5 \%$, and it is noted that these values are below that found in the literature, with variations between 30 and $40 \%$ for forage pastures (Velásquez et al., 2010; Neres et al., 2011; Silva et al., 2012; Sanches et al., 2015). However, Nussio et al. (2011) concluded that the ADF maximum limit is $30 \%$ and in this case all treatments were below this value (Table 4). Since the percentages of ADF represent lignocellulose (lignin and cellulose), that is, the less digestible portion of the cell wall and according to Nussio et al. (2011), the lignin present in the cell walls is what most limits the digestion of fiber, mainly to indicate the maturity of the tissue.

By relating the concentration of ADF and NDF mainly composed of proteins, fats, soluble carbohydrates and pectin, and other water soluble constituents, obtained values (Table 4) afforded the voluntary intake, demonstrating good palatability and digestibility Urochloa hybrid, corroborating with Argel et al. (2007).

The CP grasses and legumes have in their composition a percentage of N non-protein (Santos \& Pedroso, 2011), and fertilizers, especially nitrogen, in addition to increasing the production of forage, increase $\mathrm{CP}$ content of the fodder, and in some cases, decrease the fiber content, thus contributing to the improvement of Urochloa hybrid quality (Table 4).

The levels of $\mathrm{CP}$ found in the present work are above $8 \%$ of $\mathrm{CP}$, a minimum considered to meet the requirements of nitrogenous compounds of ruminal microorganisms, and do not compromise the use of the available energy substrates (Lazzarini et al., 2009). Argel et al. (2007) concluded that the adequate CP content for Urochloa hybrid is between 8 and 16\%, corroborating with the value observed in the present study (Table 4).

No interference of biostimulant doses $(p>0.05)$ was observed on the macro and micronutrient contents of Urochloa aerial part (Table 5). 
Table 5. Levels of macro and micronutrients foliar Urochloa hybrid in function of different doses of biostimulant

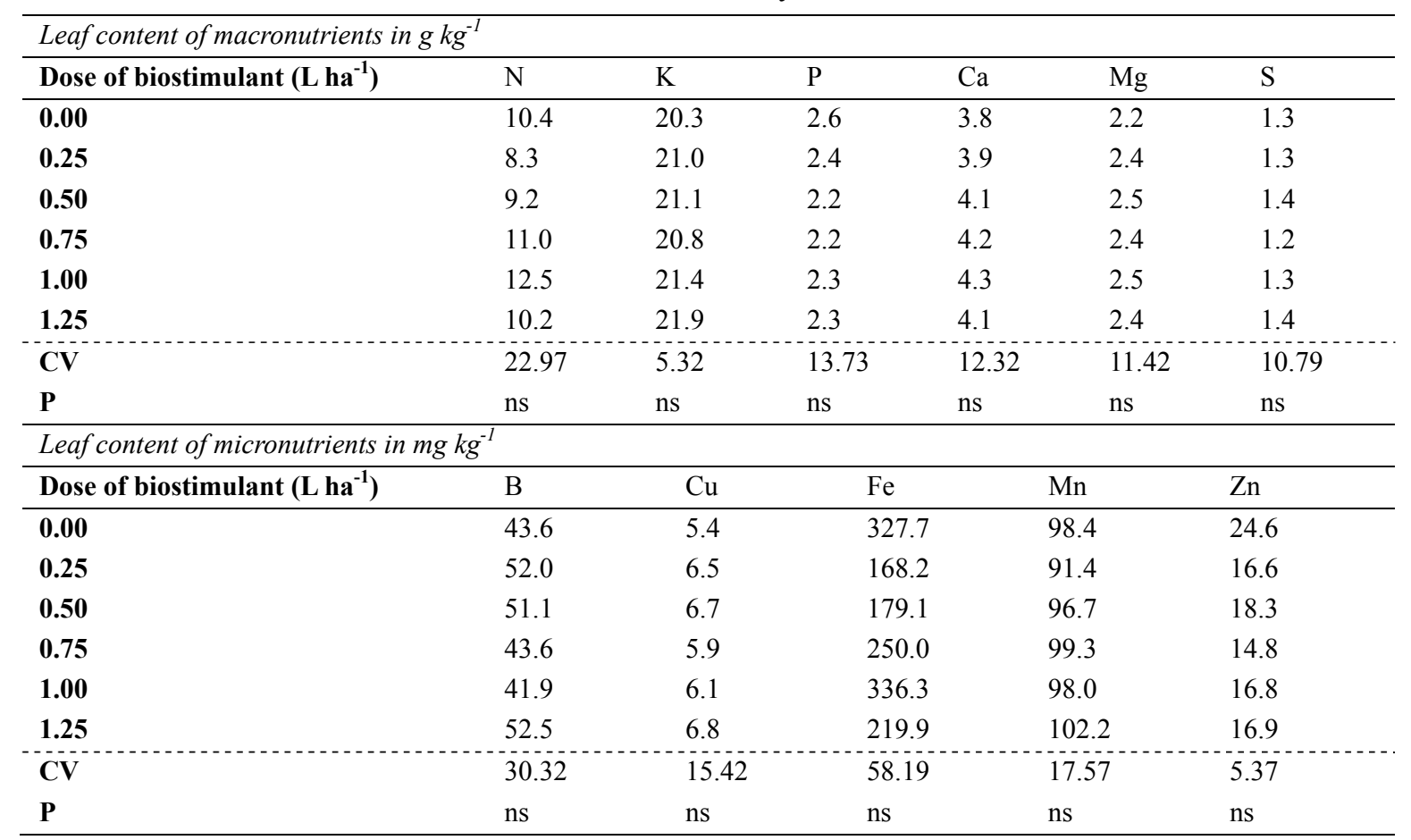

Note. C.V. (\%): Coefficient of variation. P-value: ns: not significance to $1 \%$ and $5 \%$.

The $\mathrm{N}$ is among the most important factors to determine the level of production per area and its absorption directly influences the $\mathrm{CP}$ content of the forage (Lazzarini et al., 2009). In the present study, the $\mathrm{N}$ content in Urochloa in the aerial part was in the range of 13 to $20 \mathrm{~g} \mathrm{~kg}^{-1}$ (Oliveira et al., 2007), and it is noted that no treatment obtained adequate levels of $\mathrm{N}$ (Table 5), which was not expected due to high nitrogen fertilization (30 $\left.\mathrm{kg} \mathrm{ha}^{-1}\right)$ in all treatments. The dose of $1.0 \mathrm{~L} \mathrm{ha}^{-1}$ of biostimulant had the leaf content closest to the appropriate one, $12.5 \mathrm{~g} \mathrm{~kg}^{-1}$.

In the present work, the two elements mentioned are in the range of 0.8 to $3 \mathrm{~g} \mathrm{~kg}^{-1}$ and for $\mathrm{K}$ of 12 to $30 \mathrm{~g} \mathrm{~kg}^{-1}$ (Oliveira et al., 2007). content. The foliar contents of the nutrients $\mathrm{Ca}, \mathrm{Mg}$ and $\mathrm{S}$ were within the appropriate range in the aerial part (Table 5), being 3 to $6 \mathrm{~g} \mathrm{~kg}^{-1} ; 1.5$ to $4.0 \mathrm{~g} \mathrm{~kg}^{-1}$ and 0.8 to $2.5 \mathrm{~g} \mathrm{~kg}^{-1}$ respectively (Perondi et al., 2007).

According to Oliveira et al. (2007) the appropriate values for micronutrients are: B between 10 to $25 \mathrm{mg} \mathrm{kg}^{-1} ; \mathrm{Fe}$ between 100 and $487 \mathrm{mg} \mathrm{kg}^{-1}$; Mn between 40 to $250 \mathrm{mg} \mathrm{kg}^{-1}$; $\mathrm{Zn}$ between 20 and $50 \mathrm{mg} \mathrm{kg}^{-1}$. Analyzing the leaf contents, it was verified that these nutrients were found within the appropriate range (Table 5).

The content of $\mathrm{Cu}$ in the forage should be at least $5 \mathrm{mg} \mathrm{kg}^{-1}$ (Sousa et al., 2005), for all dosages desirable nutrient levels were observed (Table 5). Micronutrients are required by plants in small quantities, although the lack of any one can limit plant growth even when all other essential nutrients are present in adequate quantities. Micronutrients have essential functions that take part in the metabolism of plants, and act mainly as catalysts of various enzymes (Lopes, 1998).

In general, the biostimulant acts directly on root absorption and indirectly, when it has an effect on increasing or reducing the demand for several compounds, including minerals (Vieira \& Castro, 2004). In the papers reviewed, it was observed that the substances regulating growth influenced several physiological phenomena related to mineral absorption, such as membrane conductivity and metabolic use of ions (Van Stenveninck, 1976). However, for Albuquerque et al. (2000), plant regulators that inhibit the synthesis of gibberellins and branch growth have influenced the concentration of nutrients in various perennial crops.

The indirect effect of biostimulant on mineral absorption, which occurs through vigor control, was based on the relationship between mineral absorption and growth demand. According to the concepts of Russell (1977), the absorption of nutrients is mainly determined by the metabolic demand of the plant. Phytohormones regulated 
plant growth by different root management, finding a linear relationship between Ca and $\mathrm{K}$ uptake and increment in forage (Richards \& Rowe, 1977).

The accumulation of $\mathrm{N}$ in the forage of Urochloa hybrid suffered interference $(\mathrm{p}<0.05)$ from the doses of biostimulant and the other nutrients $(\mathrm{K}, \mathrm{P}, \mathrm{Ca}, \mathrm{Mg}, \mathrm{S}, \mathrm{B}, \mathrm{Cu}, \mathrm{Fe}, \mathrm{Mn}$ and $\mathrm{Zn}$ ) did not suffer biostimulant interference (Table 6).

Table 6. Accumulation of macro and micronutrients in leaves of Urochloa hybrid in function of different doses of biostimulant

\begin{tabular}{|c|c|c|c|c|c|c|}
\hline \multicolumn{7}{|c|}{ Accumulation of macronutrients in $\mathrm{kg} \mathrm{ha}^{-1}$ of DM } \\
\hline Dose of biostimulant $\left(\mathrm{L} \mathrm{ha}^{-1}\right)$ & $\mathrm{N}$ & $\mathrm{K}$ & $\mathrm{P}$ & $\mathrm{Ca}$ & $\mathrm{Mg}$ & $\mathrm{S}$ \\
\hline 0.00 & 57.1 & 115.6 & 14.7 & 21.8 & 12.7 & 7.1 \\
\hline 0.25 & 52.4 & 135.1 & 15.1 & 24.7 & 15.4 & 8.3 \\
\hline 0.50 & 66.5 & 151.2 & 15.3 & 29.8 & 17.8 & 9.9 \\
\hline 0.75 & 75.3 & 143.8 & 15.2 & 28.4 & 16.2 & 8.5 \\
\hline 1.00 & 94.3 & 168.5 & 18.0 & 33.7 & 19.7 & 10.1 \\
\hline 1.25 & 77.6 & 166.7 & 17.1 & 31.1 & 18.3 & 10.3 \\
\hline $\mathbf{C V}$ & 24.67 & 17.21 & 21.72 & 20.15 & 19.60 & 18.78 \\
\hline $\mathbf{P}^{\mathbf{1}}$ & ns & ns & ns & ns & ns & ns \\
\hline \multicolumn{7}{|c|}{ Accumulation of micronutrients in $\mathrm{g} \mathrm{ha} \mathrm{C}^{-1}$ of $\mathrm{DM}$} \\
\hline Dose of biostimulant $\left(\mathrm{L} \mathrm{ha}^{-1}\right)$ & $\mathrm{B}$ & $\mathrm{Cu}$ & $\mathrm{Fe}$ & & $\mathrm{Mn}$ & $\mathrm{Zn}$ \\
\hline 0.00 & 251.8 & 31.0 & 1814.6 & & 563.0 & 145.0 \\
\hline 0.25 & 339.3 & 41.6 & 1060.1 & & 588.1 & 106.2 \\
\hline 0.50 & 370.2 & 48.3 & 1289.2 & & 702.2 & 131.9 \\
\hline 0.75 & 313.3 & 40.8 & 1668.1 & & 685.9 & 103.7 \\
\hline 1.00 & 339.4 & 46.7 & 2439.8 & & 749.0 & 130.4 \\
\hline 1.25 & 408.8 & 52.8 & 1702.4 & & 785.5 & 128.4 \\
\hline $\mathrm{CV}$ & 33.65 & 22.02 & 51.89 & & 21.84 & 17.39 \\
\hline $\mathbf{P}^{1}$ & ns & ns & $\mathrm{ns}$ & & ns & $\mathrm{ns}$ \\
\hline
\end{tabular}

Note. C.V. (\%): Coefficient of variation. P-value: ns: not significance to $1 \%$ and $5 \%$.

Studies conducted with U. brizantha by Faquin et al. (2000), in Cerrado latosols, showed that the symptoms of P deficiency in forage were the most severe, which did not corroborate with the results found in the present study. In the analysis performed at the beginning of the experiment it was found that $\mathrm{P}$ content in the soil was below the recommended level (Table 1) and when analyzing the leaf contents (Table 5) and the accumulation of $P$ in the plant (Table 6) were within the recommendation range. According to Argel et al. (2007), the use of $\mathrm{N}$ by Urochloa hybrid improved the adequate levels of minerals, and may explain the improvement in leaf content of $\mathrm{P}$, since this nutrient was not available to the plant in the form of fertilizer.

The macronutrients were accumulated in the following order, $\mathrm{K}>\mathrm{N}>\mathrm{P}>\mathrm{Ca}>\mathrm{Mg}>\mathrm{S}$ and $\mathrm{Fe}>\mathrm{Mn}>\mathrm{B}>\mathrm{Zn}>$ $\mathrm{Cu}$ for micronutrients (Table 6), corroborating Braz et al. (2004) for Urochloa.

The biostimulant has the capacity to stimulate root development, increasing the absorption of water and nutrients by the roots, and can also favor the hormonal balance of the plant (Vieira \& Castro, 2004). Was made available to the Urochloa hybrid, together with the application of the biostimulant and as it was applied in all plots, even in the control. The progressive increase of the accumulation up to the maximum dose demonstrated that the product potentiated the absorption of $\mathrm{N}$ by the plant and made $\mathrm{N}$ available to the plant.

No regression models were found that adjusted for the increase in the accumulation of other nutrients $(\mathrm{K}, \mathrm{P}, \mathrm{Ca}$, $\mathrm{Mg}, \mathrm{S}, \mathrm{B}, \mathrm{Cu}, \mathrm{Fe}, \mathrm{Mn}$ and $\mathrm{Zn}$ ) in the leaves of Urochloa hybrid, but for all, up to $45.8 \%$ over that produced at the control (Table 6). In the results found in the literature, $\mathrm{K}$ is the macronutrient of greatest accumulation, followed by $\mathrm{N}$, these nutrients being the most absorbed and accumulated in the vegetal tissue of the plants in the Cerrado region (Pariz et al., 2011; De Mendonça et al., 2014). This corroborated with the accumulation found in the present study (Table 6). 


\section{Conclusions}

Biostimulants promote an increase in the accumulation of DM and in the rate of accumulation of forage, leaves and stems of Urochloa hybrid Convert HD364 and reduce the percentage of dead material and the relation of L:S of Urochloa hybrid Convert HD364.

\section{Acknowledgements}

The authors thank the Agrarian Science Institute (ICIAG-UFU), the Coordination for the Improvement of Higher Education Personnel (CAPES) and Stoller® for financial support.

\section{References}

Albrecht, L. P., Braccini, A. L., Ávila, M. R., Barbosa, M. C., Ricci, T. T., \& Albrecht, A. J. P. (2009). Aplicação de biorregulador na produtividade do algodoeiro e qualidade de fibra. Scientia Agraria, 10, 191-198. https://doi.org/10.5380/rsa.v10i3.14474

Albrecht, L. P., Braccini, A. L., Scapim, C. A., Ávila, M. R., \& Albrecht, A. J. P. (2012) Biorregulador na composição química e na produtividade de grãos de soja. Revista Ciência Agronômica, 43, 774-782. https://doi.org/10.1590/S1806-66902012000400020

Albrecht, L. P., Braccini, A. L., Scapim, C. A., Ávila, M. R., Albrecht, A. J. P., \& Ricci, T. T. (2011) Manejo de biorregulador nos componentes de produção e desempenho das plantas de soja. Bioscience Journal, 27, 865-876.

Albuquerque, T. C. S., Dechen, A. R., \& Castro, P. R. C. (2000). Retardadores de crescimento e características nutricionais das cultivares de videira Thompson Seedless e Itália. Scientia Agricola, 57, 45-53. https://doi.org/10.1590/S0103-90162000000100009

Argel, P. J., Miles, J. W., Guiot, J. D., Cuadrado, H., \& Lascano, C. E. (2007). Mulato II (Brachiaria híbrida CIAT 36087): Graminea de alta qualidade e produção forrageira, resistente as cigarrinhas e adaptada a solos tropicais ácidos. Cali: CIAT.

Berchielli, T. T., Messana, J. D., \& Canesin, R. C. (2012). Produção de metano entérico em pastagens tropicais. Revista Brasileira de Saúde e Produção Animal, 13, 954-968. https://doi.org/10.1590/S1519-9940201 2000400010

Bonfim-Silva, E. M., \& Monteiro, F. A. (2010). Nitrogênio e enxofre na adubação e em folhas diagnósticas e raízes do capim braquiária em degradação. Revista Brasileira de Zootecnia, 39, 1641-1649. https://doi.org/ $10.1590 / \mathrm{S} 1516-35982010000800004$

Braz, A. J. B. P., Silveira, P. D., Kliemann, H. J., \& Zimmermann, F. J. P. (2004). Acumulação de nutrientes em folhas de milheto e dos capins braquiária e mombaça. Pesquisa Agropecuária Tropical, 34, 83-87.

Campos, F. P. de, Nussio, C. M. B., \& Nussio, L. G. (2004). Métodos de análise de alimentos (p. 135). Piracicaba, FEALQ.

Cantarutti, R. B., Barros, N. F., Martinez, H. E. P., \& Novais, R. F. (2007). Avaliação da fertilidade do solo e recomendação de fertilizantes. In R. F. Novais, V. V. H. Alvarez, N. F. Barros, R. L. F. F. Fontes, R. B. Cantarutti, \& J. C. L. Neves (Eds.), Fertilidade do solo (pp. 645-737). Viçosa, SBCS.

Castro, G. S. A., Borgiani, J. C., Silva, M. G., Gazola, E., \& Rosolem, C. A. (2008). Tratamento de sementes de soja com inseticidas e um bioestimulante. Pesquisa Agropecuária Brasileira, 43, 1311-1318. https://doi.org/ 10.1590/S0100-204X2008001000008

Corrêa, L. de A., Cantarella, H., Primavesi, A. C., Primavesi, O., Freitas, A. R. De, \& Silva, A. G. de (2007) Efeito de fontes e doses de nitrogênio na produção e qualidade da forragem de capim-coastcross. Revista Brasileira de Zootecnia, 36, 763-772. https://doi.org/10.1590/S1516-35982007000400003

Costa, K. A. P., Oliveira, I. P., Faquin, V., Neves, B. P., Rodrigues, C., \& Sampaio, F. M. T. (2007). Intervalo de corte na produção de massa seca e composição químico-bromatológica da Brachiaria brizantha cv. MG-5. Ciência e Agrotecnologia, 31, 1197-1202. https://doi.org/10.1590/S1413-70542007000400037

Costa, N. R., Domingues, M. C. S., \& Rodrigues, J. D. (2010). Desempenho do cafeeiro Icatu vermelho sob ação de biorregulador aplicado em fases reprodutivas da cultura. Agrarian, 2, 113-130.

De Almeida, A. Q., Soratto, R. P., Broetto, F., \& Cataneo, A. C. (2014). Nodulation, biochemical aspects, growth and yield of common bean according bioestimulant application. Semina: Ciências Agrárias, 35, 77-88. 
De Campos, M. F., Ono, E. O., \& Rodrigues, J. D. (2015). Desenvolvimento da parte aérea de plantas de soja em função de reguladores vegetais. Ceres, 56, 74-79.

De Mattos, W. T., Werner, J. C., Colozza, M. T., Gerdes, L., Dos Santos, L. E., \& Giacomini, A. A. (2008). Avaliação de duas cultivares de Panicum maximum Jacq. submetidas a doses de nitrogênio em lotação rotacionada com ovinos. Boletim de Indústria Animal, 65, 289-302.

De Mendonça, V. Z., De Mello, L. M. M., Andreotti, M., \& Yano, E. H. (2014). Teor e acúmulo de nutrientes no consórcio de milho com forrageiras no sistema plantio direto. Revista Brasileira de Ciências Agrárias, 9, 330-337. https://doi.org/10.5039/agraria.v9i3a3391

Fagundes, J. L., Fonseca, D. M., Gomide, J. A. G, Nascimento Júnior, D., Vitor, C. M. T., Morais, R. V., ... Martuscello, J. A. (2005) Acúmulo de forragem em pastos de Brachiaria decumbens adubados com nitrogênio. Pesquisa Agropecuária Brasileira, 40, 397-403. https://doi.org/10.1590/S0100-204X20050 00400012

Fagundes, J. L., Fonseca, D. M., Morais, R. V., Mistura, C., Vitor, C. M. T., Gomide, J. A., ... Lambertucci, D. M. (2006) Avaliação das características estruturais do capim-braquiária em pastagens adubadas com nitrogênio nas quatro estações do ano. Revista Brasileira de Zootecnia, 35, 30-37. https://doi.org/10.1590/S151635982006000100004

Faquin V., Lima, D. V., Furtini Neto, A. E., Moraes, A., Curi, N., \& Higa, N. T. (2000) Nutrição mineral do braquiarão e da soja cultivados em Latossolos sob Cerrado da região de Cuiabá-MT. Ciência e Agrotecnologia, 24, 110-117.

Ferreira, L. A., Oliveira, J. A., Von Pinho, E. V. R., \& Queiroz, D. L. (2007) Bioestimulante e fertilizante associados ao tratamento de sementes de milho. Revista Brasileira de Sementes, 29, 80-89. https://doi.org/ 10.1590/S0101-31222007000200011

Kanno, T., Macedo, M. C. M., Euclides, V. P. B., Bonno, J. A., Santos Junior, J. D. G., Rocha, M. C., \& Beretta, L. G. R. (1999). Root biomass of five tropical grass pastures under continuous grazing in Brazilian Savannas. Grassland Science, 45, 9-14. https://doi.org/10.14941/grass.45.9

Kerbauy, G. B. (2008). Fisiologia Vegetal (2nd ed., p. 431). Rio de Janeiro, Editora Guanabara Koogan Ltda.

Lazzarini, I., Detmann, E., Sampaio, C. B., Paulino, M. F., Valadares Filho, S. C., Souza, M. A., \& Oliveira, F. A. (2009). Dinâmicas de trânsito e degradação da fibra em detergente neutro em bovinos alimentados com forragem tropical de baixa qualidade e compostos nitrogenados. Arquivo Brasileiro de Medicina Veterinária e Zootecnia, 61, 635-647. https://doi.org/10.1590/S0102-09352009000300017

Lopes, A. S. (1998). Manual internacional de fertilidade do solo (2nd ed., p. 177). rev. e ampl. São Paulo, Anda/Potafos.

Malavolta, E. (2006). Manual de nutrição mineral de plantas (1st ed., p. 638). São Paulo: Editora Agronômica Ceres.

Mertens, D. R. (2002). Gravimetric determination of amylase-treated neutral detergent fiber in feeds with refluxing in beaker or crucibles: collaborative study. Journal of AOAC International, 85, 1217-1240.

Neres, M. A., Castagnara, D. D., Mesquita, E. E., Jobim, C. C., Três, T. T., Oliveira, P. S. R., \& Oliveira, A. A M. D. A. (2011). Production of tifton 85 hay overseeded with white oats or ryegrass. Revista Brasileira de Zootecnia, 40, 1638-1644. https://doi.org/10.1590/S1516-35982011000800003

Neto, D. D., Dario, G. J. A., Barbieri, A. P. P. \& Martin, T. N. (2014). Bioestimulant action on agronomic efficiency of corn and common beans. Bioscience Journal, 30, 371-379.

Nogueira, A. R. de A., \& Souza, G. B. de. (2005). Manual de laboratórios: Solo, água, nutrição vegetal, nutrição animal e alimentos (p. 334). São Carlos, Embrapa Pecuária Sudeste.

Nogueira, R. J. M. C., \& Santos, R. C. dos (2000). Alterações fisiológicas no amendoim submetido ao estresse hídrico. Revista Brasileira de Engenharia Agrícola e Ambiental, 4, 41-45. https://doi.org/10.1590/S141543662000000100008

Nussio, L. G., Campos, F. P., \& Lima, M. L. M. (2011). Metabolismo de carboidratos estruturais. In T. T. Berchielli, A. V. Pires, \& De S. G. Oliveira (Eds.), Nutrição de ruminantes (pp. 193-234). Jaboticabal, Funep. 
Oliveira, P. P. A., Marchesin, W., Luz, P. H. C., \& Herling, V. R. (2007). Guia de identificação de deficiências nutricionais em Brachiaria brizantha cv. Marandu (p. 38). São Carlos: Embrapa Pecuária Sudeste.

Paciullo, D. S. C., Lopes, F. C. F., Malaquias Junior, J. D., Viana Filho, A., Rodriguez, N. M., Morenz, M. J. F., \& Aroeira, L. J. M. (2009). Características do pasto e desempenho de novilhas em sistema silvipastoril e pastagem de braquiária em monocultivo. Pesquisa Agropecuária Brasileira, 44, 1528-1535. https://doi.org/ 10.1590/S0100-204X2009001100022

Pariz, C. M., Andreotti, M., Azenha, M. V., Bergamaschine, A. F., Mello, L. M. M. De, \& Lima, R. C. (2011). Produtividade de grãos de milho e massa seca de braquiárias em consórcio no sistema de integração lavoura-pecuária. Ciência Rural, 41, 875-882. https://doi.org/10.1590/S0103-84782011000500023

Rampim, L., Rodrigues-Costa, A. C. P., Nacke, H., Klein, J., \& Guimarães, V. F. (2012). Qualidade fisiológica de sementes de três cultivares de trigo submetidas à inoculação e diferentes tratamentos. Revista Brasileira de Sementes, 34, 678-685. https://doi.org/10.1590/S0101-31222012000400020

Richards, D., \& Rowe, R. N. (1977). Effects of root restriction, root pruning and 6-benzylaminopurine on the growth of peach seedlings. Annual Botany, 41, 729-740. https://doi.org/10.1093/oxfordjournals.aob. a085347

Rolim, G. D. S., Camargo, M. D., Lania, D. G., \& Moraes, J. D. (2007). Classificação climática de Köppen e de Thornthwaite e sua aplicabilidade na determinação de zonas agroclimáticas para o estado de São Paulo. Bragantia, 66, 711-720. https://doi.org/10.1590/S0006-87052007000400022

Russell, R. S. (1977). Plant Root Systems: Their function and interaction with the soil (p. 298). London: Mc Graw-Hill.

Sanches, A. C., Gomes, E. P., Rickli, M. E., Fasoli, N. J. P., Soares, M. R. C., \& Goes, R. H. T. B. De. (2015). Produtividade e valor nutritivo do capim Tifton 85 irrigado e sobressemeado com aveia. Revista Brasileira de Engenharia Agrícola e Ambiental, 19, 126-133. https://doi.org/10.1590/1807-1929/agriambi.v19n2p126133

Santos, F. A. P., \& Pedroso, A. M. (2011). Metabolismo De Proteínas. In T. T. Berchielli, A. V. Pires, \& S. G. Oliveira (Eds.), Nutrição de ruminantes (pp. 265-392). Jaboticabal: FUNEP.

Santos, H. G. dos, Jacomine, P. K. T., Anjos, L. H. C. dos, Oliveira, V. A. de, Lumbreras, J. F., Coelho, M. R., ... Oliveira, J. B. de (2013). Sistema brasileiro de classificação de solos (3rd ed., p. 353). Brasília, Embrapa.

Santos, L. M., De Siqueira, F. T., De Siqueira, G. B., \& Calçado, J. P. A. (2015). Potencial de estabelecimento da Brachiaria híbrida cultivar Mulato II (Convert HD364) no estado do Tocantins. Nativa, 3, 224-232.

Serafim, R. S. (2010). Produção e composição química da Brachiaria brizantha cv. Marandu adubada com água residuária de suinocultura (p. 96, Tese Doutorado em Produção Vegetal, Faculdade de Ciências Agrárias e Veterinárias, UNESP, Jaboticabal).

Serciloto, C. M., Castro, P. R. D. C., \& Tavares, S. (2007). Effects of mbta [n, n-diethyl-2-(4-metylbenzyloxy) ethylamine hydrochloride] on yield and fruit quality of 'pêra' sweet orange (Citrus sinensis L. Osbeck). Revista Brasileira de Fruticultura, 30, 596-603.

Silva, C. D., Menezes, L. D., Ziech, M. F., Kuss, F., Ronsani, R., Biesek, R. R., \& Lisbinski, E. (2012). Sobressemeadura de cultivares de aveia em pastagem de estrela africana manejada com diferentes resíduos de forragem. Semina: Ciências Agrárias, 33, 2441-2450. https://doi.org/10.5433/1679-0359.2012v33n $6 \mathrm{p} 2441$

Silva, D. J., \& Queiroz, A. C. (2006). Análise de alimentos: Métodos quimicos e biológicos (3rd ed., p. 235). Viçosa, UFV.

Silva, M. A., Cato, S. C., \& Costa, A. G. F. (2010). Produtividade e qualidade tecnológica da soqueira de cana-de-açúcar submetida à aplicação de biorregulador e fertilizantes líquidos. Ciência Rural, 24, 23-33. https://doi.org/10.1590/S0103-84782010005000057

Sousa, D. M. G. de, Lobato, E., \& Rein, T. A. (2005). Uso de gesso agrícola nos solos dos cerrados (p. 19). Planaltina, DF: Embrapa-CPAC.

Taiz, L., \& Zeiger, E. (2013). Fisiologia vegetal (5th ed., p. 918). Porto Alegre, Artmed. 
Van Steveninck, R. F. M. (1976). Effect of hormones and related substances on ion transport. In U. Luttge, \& M. G. Pitman (Eds.), Encyclopedia of plant physiology (pp. 307-342). Springer, Berlin, Heidelberg. https://doi.org/10.1007/978-3-642-66230-0_7

Velásquez, P. A. T., Berchielli, T. T., Reis, R. A., Rivera, A. R., Dian, P. H. M., \& Teixeira, I. A. M. A. (2010) Composição química, fracionamento de carboidratos e proteínas e digestibilidade in vitro de forrageiras tropicais em diferentes idades de corte. Revista Brasileira de Zootecnia, 6, 1206-1213. https://doi.org/ $10.1590 / \mathrm{S} 1516-35982010000600007$

Vieira, E. L. (2001). Ação de bioestimulante na germinação de sementes, vigor de plântulas, crescimento radicular e produtividade de soja (Glycine max (L.) Merrill), feijoeiro (Phaseolus vulgaris L.) e arroz (Oryza sativa L.) (p. 122, Tese de Doutorado em Agronomia. Escola Superior de Agricultura "Luiz de Queiroz"- Universidade de São Paulo, Piracicaba).

Vieira, E. L., \& Castro, P. R. C. (2004). Ação de bioestimulante na cultura da soja (Glycine max (L.) Merrill) (p. 47). Cosmópolis: Stoller do Brasil.

\section{Copyrights}

Copyright for this article is retained by the author(s), with first publication rights granted to the journal.

This is an open-access article distributed under the terms and conditions of the Creative Commons Attribution license (http://creativecommons.org/licenses/by/4.0/). 